\title{
NO VAZIO DE UMA DISTÂNCIA TOMADA: ALTHUSSER E A PRÁTICA DA FILOSOFIA
}

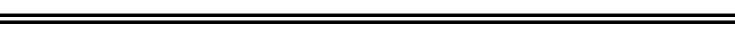

Alexandre Pinto Mendes*

Resumo: Nosso objetivo é discutir as condições e implicações do deslocamento realizado por Althusser entre a definção da filosofia como "teoria da prática teórica" e a definição da filosofia como luta e tomada de posição sobre o vazio. Levantamos a hipótese sobre se seria adequado aplicar à obra de althusser o conceito de ruptura ou corte epistemológico, o que nos permitiria compreender a passagem do materialismo dialético ao materialismo dos encontros ou aleatório como "revolução teórica" do próprio Althusser.

Palavras-chave: Althusser; definição; filosofia; prática; luta.

\section{Observações iniciais}

O que pretendemos abordar nesta comunicação é o deslocamento que se dá na obra de Althusser entre uma primeira definição da filosofia como "teoria da prática teórica" e uma segunda definição da filosofia, a partir de 1967/68, como "luta de classes na teoria". Neste deslocamento, podemos ver não só uma concepção muito particular do exercício filosófico, associada ao materialismo e indistinta da própria produção teórica de Althusser, mas também a constatação de que as ideias de "ruptura" ou

* Professor do Departamento de Ciências Jurídicas da Universidade Federal Rural do Rio de Janeiro. Doutorando em Teoria do Estado e Direito Constitucional pela PUC-Rio. Graduado em Filosofia pela UFRJ. 
“corte epistemológico" não são, pois, estranhas ao próprio pensamento de Althusser, algo que ele mesmo percebia.

O que ninguém pode contestar, ao me ler, é que sempre tive a consciência de minha solidão radical em face de minha intervenção, da extrema responsabilidade que, em última análise, repousava sobre mim, e dos 'riscos e perigos' aos quais minha solidão e minha responsabilidade me impunham (...) Como, nessas condições, não dar a meu pensamento a forma abrupta de um corte, de uma ruptura? Aí se reconhecerá um de meus temas, na realidade objetivamente muito dúbios, que sempre freqüentaram minha reflexão. Como igualmente escapar da necessidade de marcar, na própria linguagem de meu discurso, o abrupto desse corte pelo abrupto de fórmulas abruptas (...)? (Althusser 11, pp. 155-156)

No seu "curso de filosofia para cientistas" (1967), Althusser enuncia a tese de que “(...) a filosofia não se ilustra, não se aplica. Não pode aprender-se senão praticando-a, porque ela não existe senão em sua prática" (Althusser 4, p. 33). Althusser rejeita, portanto, qualquer possibilidade de conceber o movimento de definição da filosofia na forma de uma "tomada de consciência" pelo sujeito de conhecimento. Aliás, “(...) nunca há definição, a não ser de uma diferença (...)” (Althusser 7, p. 12). O que é captado pela definição, contudo, não é uma diferença de objeto mas de relação com o objeto. E o que determina a forma específica desta relação que será designada pela definição não é uma disposição do aparelho cognitivo do sujeito, mas a estrutura do campo de problemas ou problemática na qual está situada a relação:

Não é a matéria da reflexão o que caracteriza ou qualifica a reflexão, mas a modalidade de reflexão, a relação efetiva que esta reflexão mantém com seus objetos, ou seja, a problemática fundamental a partir da qual são pensados os objetos desse pensamento. (Althusser 1, p. 54)

\section{A filosofia como teoria da prática teórica: A Favor de Marx e Ler O Capital}

Esta ideia de que a relação de um pensamento filosófico com seus objetos é determinada por sua problemática constitui o recurso fundamental para a reflexão sobre a filosofia de Marx. Os conceitos bachelardianos como "ruptura epistemológica" e "obstáculo epistemológico" intervêm na medida em que permitem conceituar as relações entre as problemáticas de Marx e de seus antecessores como relações de descontinuidade radical.

O que marca a passagem da ideologia à ciência, no caso da leitura marxiana da Economia Política seria, pois, uma mudança de problemática, uma mudança estrutural, já que a problemática não é senão a estrutura de um campo teórico no qual surgem os objetos de conhecimento. A filosofia intervém aqui como reflexão sobre a estrutura do campo teórico desenhado pela ciência, razão pela qual será definida como "teoria da prática teórica". É importante, portanto, situar as condições e limites do recurso à noção de estrutura na definição de uma problemática. Pensar um campo ou problemática como estrutura significa, sobretudo, estabelecer o primado das relações sobre os elementos do campo. Todavia, Althusser criticará o "estruturalismo" "que se quer chegaria a ser uma "filosofia"1- por seu formalismo, ou por não pensar a combinatória de elementos na estrutura sob a determinação de dominância-subordinação de certas relações por outras no interior de um todo: no caso, a determinação "em última instância" pela economia. Ou seja, o estruturalismo ignoraria relações de causalidade estrutural entre os elementos do todo, postulando a produção do real como processo arbitrário ou fortuito (aleatório) de combinação de elementos. 
A originalidade de Marx, sua "imensa revolução teórica" na história da filosofia, estaria justamente em ter "mudado de terreno", em ter inaugurado uma nova problemática filosófica, seguindo o legado de Spinoza. Marx teria então alterado radicalmente a relação que a prática filosófica estabelece com seus objetos, ao conceber o conhecimento como produção no interior do modo de produção da totalidade social. Isto apesar do fato de que o próprio Marx não tenha refletido sobre esta "mudança de terreno" que realizou na sua prática. Althusser realiza seu próprio desenho teórico da problemática clássica da filosofia a partir do pensamento de Marx: com efeito, grande parte da polêmica de A Favor de Marx e Ler O Capital é dirigida contra o idealismo e o empirismo, filosofias que o pensamento marxista ou o materialismo dialético permitiu designar como "ideológicas", justamente pela natureza peculiar das relações entre estas filosofias e seus objetos, natureza determinada pela estrutura ideológica dessa problemática.

Como dirá Althusser em A Favor de Marx, “(...) não é o conteúdo imediato dos objetos pensados, senão a forma de colocar os problemas que constitui a essência ideológica última de uma ideologia (...)" (Althusser 1, p. 55). A ideologia coloca problemas e constitui objetos ideológicos, a ciência coloca problemas e constitui objetos científicos. Em ambos os casos, temos duas estruturas de problemáticas diferentes. O mérito do materialismo dialético, ou a filosofia de Marx, foi ter estabelecido a forma da relação entre o "ideológico" e o "científico": não há uma relação de continuidade entre ciência e ideologia, ao contrário

A ciência só se obtém quando se abandona o campo no qual a ideologia tem a ver com o real, ou seja, se abandona sua problemática ideológica (o pressuposto orgânico de seus conceitos fundamentais e, junto com esse sistema, a maior parte dos conceitos mesmos) para fundar 'em outro elemento' o campo de uma nova problemática, científica, a atividade de uma nova teoria. (Althusser 1, p. 159)

Toda a história da filosofia anterior se fundaria, por seu turno, em um problema ideológico: o "problema do conhecimento". Um problema artificial, para o qual se tem a resposta na sua própria formulação: as correspondências estabelecidas de antemão entre o sujeito de conhecimento e o objeto de conhecimento, entre objeto de conhecimento e objeto real. A operação de conhecimento seria de abstração/extração do que no objeto real é essencial, separando-o de sua parte inessencial. Esta essência do objeto de real é objeto de conhecimento conhecido pelo sujeito. Ela está escondida no próprio objeto real, portanto já dada no real, tanto quanto a capacidade de abstrair o inessencial e reconhecer o essencial é dada para o sujeito de conhecimento: ele já carrega em si a garantia de resolução do problema resolvido, pois todas as condições de possibilidade de todas as etapas da operação de conhecimento já existem antes mesmo do processo ter início. Tal garantia reside, em última instância, na natureza espiritual ou ideal do que é “essencial”. Daí porque há uma analogia perfeitamente possível entre sujeito e objeto. No fundo, tanto a dialética hegeliana quanto o empirismo, racionalista ou sensualista, compartilham dessa ideia do conhecimento como uma espécie de reconhecimento2, pela qual se sai em busca do que já se tem.

Marx, por sua vez, concebe o objeto de conhecimento como distinto do objeto real, e o processo de conhecimento como algo que se passa inteiramente no pensamento, e sem correspondência imediata com o processo real. Baseado no texto da Introdução à Crítica da Economia Política3, Althusser insiste a todo o momento sobre a diferença estrutural entre a dialética de Marx (materialista) e de Hegel (idealista), justamente 
porque, em Marx, há uma "desigualdade de origens" entre o processo de pensamento e o processo real, entre as contradições reais e a forma pela qual são apreendidas, não sendo o pensamento senão uma estrutura dentro da estrutura de um todo real articulado de maneira complexa. Ao passo que, em Hegel, o real e o pensamento são partes de uma totalidade articulada de maneira simples sobre uma "unidade espiritual" que é

“(...) o tipo de unidade de uma 'totalidade expressiva', isto é, de uma totalidade cujas partes sejam cada quais 'partes totais' expressivas uma das outras, e expressivas cada uma da totalidade social que as contêm, porque contendo cada uma em si, sob a forma imediata de sua expressão, a própria essência da totalidade" (Althusser 8, p. 33)

A relação entre objeto real e objeto de conhecimento é estabelecida através dessa ordem do discurso de conhecimento. Ela se dá como efeito de conhecimento do objeto real, não como reprodução ideativa do objeto no pensamento: ela é o produto de uma prática teórica, que se distingue das demais práticas pelo tipo de combinação “existente entre sua matéria-prima própria (objeto da prática teórica) seus meios de produção, e suas relações com as demais práticas da sociedade" (Althusser 7, p. 43). Esta matériaprima não é o objeto real dado, mas "fatos ideológicos" anteriores.

$\mathrm{Na}$ estrutura da nova problemática filosófica, o materialismo dialético, um novo objeto de conhecimento torna-se visível para o filósofo: a prática teórica, seja de natureza científica, seja de natureza ideológica:

A prática teórica cai sob a definição geral da prática. Trabalha sobre uma matéria (representações, conceitos, fatos) que lhes é proporcionada por outras práticas, quer sejam 'empíricas', 'técnicas' ou 'ideológicas'. Em sua forma mais geral a prática teórica não compreende só a prática teórica científica, mas também a prática teórica pré-científica, ou seja, 'ideológica' (as formas de conhecimento que constituem a pré-história de uma ciência e suas 'filosofias') (Althusser 1, p. 137).

Se o conhecimento ou teoria tem em geral essa natureza de prática que, como vimos, trabalha sobre uma matéria-prima com meios de produção determinados e produz um resultado, o próprio objeto de conhecimento, a especificidade da prática filosófica é ser uma "teoria da prática teórica" ou simplesmente Teoria com t maiúsculo:

Chamaremos Teoria (maiúscula) à teoria geral, quer dizer, a teoria da prática em geral, elaborada a partir da Teoria das práticas teóricas existentes (das ciências), que transforma em 'conhecimentos' (verdades científicas) o produto ideológico das práticas 'empíricas' (atividade concreta dos homens) existentes. Esta Teoria é a dialética materialista, que é a mesma coisa que materialismo dialético (Althusser 1, pp. 137-138).

Esta definição, no entanto, não satisfaz o critério acima enunciado. Ela não nos dá a conhecer o modo próprio de relação da filosofia com seus objetos (práticas teóricas). O próprio Althusser falará em seus Elementos de Autocrítica de um "desvio teoricista" 4 : O "desvio" a que se refere Althusser estaria em definir nestes textos a filosofia por analogia à ciência, não por sua diferença. Podemos aplicar ao próprio Althusser sua teoria da leitura sintomática, e nos perguntar o que produz essa ausência no discurso no qual lemos que a filosofia é uma "teoria da teoria". A resposta estaria, da mesma forma que Althusser trata os autores que estuda, na sua problemática: na relação entre a teoria e a prática teórica, o sentido do termo prática muitas vezes se confunde com o sentido de práxis que encontramos em Feuerbach e no jovem Marx, ou seja, práxis como atividade sensível, atividade de 
modificação/transformação de uma matéria com que a prática tem uma relação imediata, ao passo que a teoria só estabelece com esta mesma matéria uma relação mediada. Paradoxalmente, portanto, é a estrutura da problemática do jovem Marx que se insinua no texto.

A (re)solução da teoria na prática poderia ser explicada, portanto, pelo recurso à analogia das diferentes práticas sociais com a prática econômica. Haveria então uma prática teórica que lida com objetos de conhecimento ou objetos ideológicos, e uma prática teórica de segundo nível, Teoria ou materialismo dialético, que lida com os resultados das práticas teóricas "aplicadas" a objetos. Um problema filosófico diria respeito então a "um conceito ou conjunto de conceitos que atingem necessariamente as próprias formas da cientificidade ou da racionalidade (teórica) existente, as formas que definem, num momento dado o Teórico em si, isto é, o objeto da filosofia" (Althusser 8, p. 137).

Onde está o problema nesta definição analógica? Porque não desenvolvê-la?

Em primeiro lugar, ela não permite apreender a especificidade da filosofia enquanto prática superestrutural, ou seja, sua eficácia própria enquanto nível ou instância de uma totalidade social. Não é nosso objeto aqui tratar das relações entre superestrutura-infraestrutura, mas o que precisamos dizer é que a ideia de "eficácia própria" pressupõe justamente a diferença qualitativa entre as práticas superestruturais e infra-estruturais, o que a analogia com a prática econômica não permitiria captar.

Em segundo lugar, a definição tampouco é compatível com a crítica feita ao "problema do conhecimento", pois ela pressupõe uma mudança na estrutura da problemática filosófica. Ora, como o próprio Althusser reconhece a respeito da eficácia própria da ciência, de seu modo de produção peculiar, é necessário que o objeto de conhecimento sofra uma transformação. Como explicar, se a filosofia é um discurso sobre as formas puras da cientificidade, a ocorrência de revoluções teóricas em filosofia, de “acontecimentos filosóficos de alcance histórico, isto é, muito precisamente, fatos filosóficos que produzem mutação real nas relações estruturais filosóficas existentes" (Althusser 8, p. 42)? Produz-se aqui uma espécie de "vazio epistemológico", termo utilizado para designar o "efeito de desconhecimento" de uma ideologia (Althusser 1, p. 106.)

Já em Ler O Capital, contudo, encontramos indicações do que seria mais tarde desenvolvido para resolver esta "impostura" quanto à definição da filosofia. Trata-se da definição do pensamento como aparelho de pensamento:

(...) o 'pensamento' de que Marx trata no caso não é a faculdade de um sujeito transcendental ou de uma consciência absoluta, que o mundo real enfrentaria como matéria: esse pensamento também não é a faculdade de um sujeito psicológico, embora os indivíduos sejam agentes dele. Esse pensamento é o sistema historicamente constituído de um aparelho de pensamento (...) (Althusser 7, p. 42)

Que a prática da filosofia se dê em um "aparelho de pensamento" historicamente constituído nos ajuda a compreender como um efeito de conhecimento pode se processar no interior do próprio conhecimento: sem correspondência com os processos do concreto mesmo, há uma história própria dos modos de produção teórica, que tal como a história dos modos de produção econômicos, é feita de descontinuidades, rupturas e remanejamentos.

Mas a constatação do fato destas mutações estruturais não nos dá ainda a diferenciação da prática filosófica, uma vez que as estruturas, em geral, mudam. Em A Favor de Marx e Ler O Capital, Althusser parece mais preocupado em determinar a relação necessária que estas mudanças estabelecem com o todo da estrutura social, ou seja, a 
relatividade da autonomia dos diferentes níveis e instâncias do todo social, articulado como estrutura determinada em "última instância" pela economia. Apenas esta relação de necessidade" a "unidade de ruptura" das contradições sociais, "sempre-já-dado de uma unidade complexa estruturada" (Althusser 1, p. 164) - permite tornar as relações entre mudanças e permanências inteligíveis

(...) não como variações e mutações acidentais produzidas pelas 'condições' exteriores sobre um todo estruturado fixo, suas categorias e sua ordem fixas (nisto consiste o mecanismo), senão como reestruturações concretas, inscritas no 'jogo de cada categoria; em essência, o 'jogo' de cada contradição; em essência o 'jogo' das articulações da estrutura complexa de dominância que se reflete nelas (Althusser 1, p. 174)

Caso contrário, teríamos uma pulverização da eficácia das superestruturas em "fatos e acontecimentos infinitesimais, ou seja, acasos" (Althusser 1, 1967, p. 98). A dialética materialista, portanto, é um modo de pensar no qual não há espaço para a mudança aleatória, contingente, tema que será caro, como veremos, aos últimos textos de Althusser. A determinação estrutural dá conta de todas as variações possíveis como necessidade de sua contingência (Althusser 7, p. 46). As revoluções teóricas determinam mudanças na estrutura da problemática e, consequentemente, na estrutura do objeto da prática científica, inaugurando um novo domínio de conhecimento. Tal é o caso de Marx, com relação aos economistas clássicos: tratava-se um novo olhar para os fenômenos econômicos que ia além do imediatamente dado, buscando formular o conceito das determinações estruturais destes fenômenos.

Poderíamos perguntar: o que há de necessário na contingência do acontecimento teórico produzido por Marx? Marx não exprime teoricamente a novidade de seus descobrimentos, e o faz justamente pelos condicionamentos que o estado da teoria lhe impôs ou a combinação específica que foi possível produzir nos limites de uma aparelho teórico. O mesmo se deu com Freud: não encontrou "pais na teoria", ou seja, procurou em vão precedentes teóricos de sua descoberta e teve que "pensar a sua descoberta e a sua prática com conceitos teóricos importados, emprestados à Física energética, então dominante, à Economia Política e a Biologia de seu tempo" (Althusser 10, p. 52). De todo modo, a ideia de uma história dos modos de produção teóricos marcada por descontinuidades e rupturas, parece se chocar com esse sentido de causalidade estrutural que dita a "lei de suas variações". Althusser chega a dizer que pensar na necessidade da contingência significa substituir todo um sistema de categoria clássicas (Althusser 7, p 46).

Há, contudo, algumas indicações importantes fornecidas por Althusser, sobre como pensar este sentido de necessidade. Elas caminham na direção da política. Para compreendê-lo precisamos de uma "teoria da conjuntura teórica". Com efeito, a prática política tem por objeto o momento presente, a conjuntura, e seu modo próprio de relação com este objeto é a transformação de uma acumulação/condensação de contradições numa unidade de ruptura. De modo análogo, uma intervenção teórica numa conjuntura teórica de acumulação de contradições pode explicar a "necessidade da contingência" de uma ruptura epistemológica. Há problemas, por certo, em fazer uma analogia entre a prática teórica e a prática política, tanto quanto havia em fazê-lo com relação à prática econômica. Mas é no interior desta analogia que Althusser conceberá a diferenciação entre filosofia e ciência. Se é verdade que não há definição senão de uma diferença, não há como conceber uma verdadeira definição sem antes produzir esta diferença. 
Um acontecimento teórico em ciência, tal como em política, depende da transformação estrutural de um todo complexo já dado. Este todo, no caso da ciência, seria o que Althusser chama de pré-história ideológica.

Quando se constitui uma ciência, por exemplo, a física com Galileu ou a ciência da formação e da evolução das formações sociais (materialismo histórico) com Marx, trabalha-se sempre com conceitos já existentes (Vorstellungen), ou seja, uma Generalidade I, de natureza ideológica prévia. Não se 'trabalha' sobre um 'dado' objetivo puro, que seria o dos fatos puros e absolutos. Seu trabalho consiste, ao contrário, em elaborar seus próprios fatos científicos através de uma crítica dos fatos ideológicos elaborados pela prática teórica ideológica anterior. (Althusser 1, p. 151)

O mesmo se daria em filosofia: as revoluções teóricofilosóficas, como as de Spinoza e Marx, transformam a "ideologia filosófica" sobre a qual trabalham.

\section{A definição da filosofia como luta}

Ao transformarem esta ideologia filosófica, contudo, as filosofias de Spinoza e Marx não se constituem como ciências. Afirmar isto seria cair nos equívocos da filosofia dos cientistas, bem como renunciar à compreensão dos efeitos que estes dois acontecimentos filosóficos, as filosofias de Spinoza e Marx, produzem na própria historia da filosofia. As respostas e autocríticas de Althusser parecem confirmar esta lacuna:

Ao reduzir e concretizar a "ruptura" nesta única oposição, inclusive recorrente, continuada, "sem fim", entre ideologia e ciência, adotava sem crítica o ponto de vista da "ciência" em si mesma (e não só em si mesma, evidentemente!); ou melhor, esta fórmula é ainda o ponto de vista dos "agentes" da prática científica acerca de sua prática e a história de seus resultados; ou melhor ainda - pois essa fórmula segue sendo idealista - o ponto de vista da "filosofia espontânea dos cientistas" (Althusser 2, p. 32)

Na produção posterior a A Favor de Marx e Ler O Capital, portanto, o jogo fundamental das posições filosóficas se dá não mais entre "ideologia" e "ciência", mas entre "ideologia" e "filosofia", justamente porque há uma "filosofia espontânea" dos cientistas, de natureza ideológica, da qual é preciso distanciar-se. O problema então será aprofundar as pesquisas já existentes sobre a natureza própria da ideologia, seu "modo de relação" com seus objetos ideológicos, o tipo de combinação específica de seus elementos. Em resumo, a ideologia formula problemas que já carregam em si sua resposta, ou melhor, reconhece nas respostas que dá a formulação de seus problemas. Esta estrutura de reconhecimento-desconhecimento como estrutura de "inconsciência" guarda perfeita sintonia com o conceito de inconsciente da psicanálise. Com efeito, o inconsciente freudiano nos dá, segundo Althusser, os caracteres de um aparelho ideológico, pois do mesmo modo que o aparelho psíquico não é uma unidade centrada na consciência, e o ego não é senão "parte interessada no conflito do recalque inconsciente" (Althusser 10, p. 90)

A consciência é obrigatória, para que o indivíduo realize, em si, a unidade exigida pela ideologia burguesa, a fim de que os sujeitos se adequem à própria exigência ideológica de unidade, ou seja, para que a conflitiva cisão da luta de classes seja vivida pelos agentes como uma forma superior e espiritual da unidade (Althusser 10, p. 85). 
O problema não formulado na concepção de ideologia do jovem Marx é o da necessidade da representação imaginária dos indivíduos de suas condições de existência. Haveria ali, então, apenas uma reprodução da filosofia da alienação de Feuerbach, reduzindo a ideologia a um sistema de ideias, uma relação ideal invertida e distorcida entre a consciência e o real. A questão estaria, portanto, mal formulada, pois mesmo em ciência a passagem do "falso para o verdadeiro", a transformação de certos objetos teóricos em conhecimentos não se processa na consciência de um sujeito, mas no interior de uma prática teórica determinada pelo conjunto da estrutura social, ou de um "aparelho de pensamento" numa formação social dada. Tal passagem, mesmo quando ela ocorre para um sujeito, é um processo "sem Sujeito nem Fim(s)"5.

O caráter de relação imaginária com as condições reais de existência evidencia-se quando os indivíduos vivenciam esta realidade cindida como uma unidade: há um verdadeiro processo de recalcamento da luta de classes. A tomada de posição ideológica está presente na atitude espontânea do indivíduo enquanto sujeito diante da realidade cindida estruturada sob a luta de classes: ela implica um efeito de reconhecimento-desconhecimento das estruturas sociais que determinam esta mesma tomada de posição, projetando a subjetividade, o resultado de uma constituição complexa por diversos aparelhos ideológicos, na origem mesma das relações sociais. Os problemas da origem e do fim são necessariamente ideológicos: a origem nunca é mais do que a simples "faticidade do fato" 6 de um todo social sempre-já-dado. Neste sentido, Althusser dirá que "a ideologia não tem história", de modo semelhante a Freud quando afirmou que o "inconsciente era eterno", pois (oni)presente em qualquer formação social humana estruturada a partir da luta de classes. A luta de classes torna-se, assim, o verdadeiro "sujeito" do processo:
A história é certamente um 'processo sem Sujeito nem Fim(s), cujas circunstâncias dadas, nas quais 'os homens' agem como sujeitos sob a determinação de relações sociais, são o produto de uma luta de classes. Portanto, a história não tem, no sentido filosófico do termo, um Sujeito, mas um motor: a luta de classes (Althusser 5, pp. 70-71)

Retornamos à luta de classes e, portanto, à política. E é no seu interior que poderemos compreender a especificidade da prática filosófica. A segunda definição da filosofia será forjada não apenas a partir da política enquanto objeto teórico, mas no interior de suas próprias lutas políticas, contra "personagens conceituais"7, mas também adversários reais, muitas vezes se confundindo entre si. O principal deste híbrido de "personagem conceitual-adversário político" será o stalinismo: justamente o stalinismo que adotará, em sua filosofia oficial, a concepção do materialismo dialético como "ciência das ciências", nos fala Althusser em um de seus textos de intervenção na conjuntura política8. O mesmo stalinismo que tornar-se-á uma prática ideológica pautada por "conclusões sem premissas" (Althusser 6, 1978, p. 35). Na mesma direção, a urgência em romper com a "filosofia espontânea dos cientistas", ou seja, com uma concepção ideológica da filosofia como meta-ciência, está em se demarcar da noção de que a filosofia "resolve" problemas da ciência, ou busca estabelecer a origem última e a finalidade do mundo cujas leis são estabelecidas pela ciência. O "curso de filosofia para cientistas" (1967) e Lênin e a Filosofia (1968)9 podem ser consideradas, a nosso ver, como "obras de corte", onde se busca apresentar uma descrição da maneira de ser e de agir próprias da filosofia, de sua prática, para além da oposição entre ideologia e ciência.

É nestes textos que a analogia entre a prática política e a filosófica aparece pela primeira vez com nitidez e com todo seu vigor, no enunciado polêmico "a filosofia é, 'em última instância', luta de classes na teoria" 
(Althusser 5, p. 17). É na "tomada de posição" que a filosofia nos exige que está contida sua especificidade, qual seja a de "traçar linhas de demarcação, produzindo novas questões filosóficas sem fim" (Althusser 4, 1976, p. 64), ou seja, que estabelecer distinções faz surgir novas linhas de demarcação, produzindo novas questões filosóficas, ao infinito.

Produzir a diferença é, portanto, o objeto da filosofia:

Teoricamente podemos exprimir esse efeito dizendo que a filosofia 'divide' (Platão), 'traça linhas de demarcação' (Lênin), produz (no sentido de tornar manifestas, visíveis) distinções, diferenças. Toda a história da filosofia o demonstra: os filósofos passaram o seu tempo a distinguir entre a verdade e o erro, a ciência e a opinião, o inteligível e o sensível, a razão, o entendimento, o espírito e a matéria etc. (Althusser 4, p. 16)

Estas distinções e demarcações, próprias ao exercício da filosofia, não são "objetos de conhecimento", tal como os objetos da prática científica. A filosofia enuncia teses 10 que são tomadas de posição numa conjuntura teórica dada, teses estas que não podem ser provadas ou verificadas por um discurso demonstrativo, mas obedecem uma outra lógica: a da polêmica, a do choque ou encontro de argumentos opostos. Assim, a filosofia não tem objetos (Althusser 4, pp. 70-71) no sentido que uma ciência os tem, mas sim campos de intervenção nos quais ela atua para fazer aparecer o ideológico e, ao fazê-lo, tornar o "científico" visível. Esta intervenção tem por resultado prático uma re-distribuição das relações conflituais entre os termos de um determinado campo teórico, uma alteração nas relações de força entre ideias dominantes e dominadas neste campo. Assim, a luta travada em filosofia remete, em última instância, às posições de classe ligadas a estas ideias dominantes e dominadas, pois são estas posições que estruturam o campo ou uma problemática: todo trabalho "ideológico" em filosofia será produzir um "efeito de desconhecimento" sobre esta realidade cindida que está na base de sua problemática.

Por isso mesmo, o paradoxo da intervenção filosófica, enquanto tomada de posição tout court, é estar situada num limiar de indiscernibilidade com relação à tomada de posição ideológica. Althusser nos diz, inclusive, que as palavras teóricas da ideologia e da filosofia seriam as mesmas, com a diferença de que "a filosofia age modificando as palavras e sua disposição" (Althusser 4, p. 76). A filosofia, pois, age sobre a repetição dos mesmos termos que a ideologia, e neste posicionamento produz diferença, ao passo que o posicionamento ideológico repete os termos para manter as relações de força entre eles exatamente como as encontra. No limite, esta repetição seria a repetição de uma luta entre duas tendências fundamentais: o idealismo e o materialismo (Althusser 3, p. 34.). Em última instância, todo "jogo" da filosofia se daria na colocação estratégica de um dos termos do par matéria-espírito "no poder" (mise en pouvoir), ao passo que a ideologia apenas reproduz as relações de poder existentes. Mas estes termos, neles mesmos, seriam indefiníveis: sua definição é apenas oposicional, ou seja, um termo deve sua definição apenas à subordinação do outro. Há, portanto, um "jogo por nada": "a filosofia é este lugar teórico estranho onde não se passa propriamente nada, nada a não ser esta repetição de nada. Dizer que não se passa nada em filosofia é dizer que a filosofia não leva a nenhuma parte por que ela não vai a nenhuma parte"11.

Esta forma paradoxal de apresentar a prática filosófica - o "vazio de uma distância tomada" (Althusser 3, p. 40) - e, portanto, de tomar uma posição em filosofia é essencial para que situemos os últimos textos de Althusser, relativos ao "materialismo dos encontros" ou "materialismo aleatório": nestes textos, reaparece esta ideia de que a filosofia é um Kampfplatz, campo de batalha entre tendências - cuja origem é Kant - a que Althusser se refere em Lênin e a filosofia. Ela obedece a uma necessidade, a um só tempo filosófica e política, de provocar um 
“escândalo materialista", enunciando, a exemplo de Maquiavel "teseslimite, em que, para tornar o pensamento possivel se ocupe o lugar do impossivel" (Althusser 5, p. 135).

Esse lugar do impossível é o lugar da própria filosofia althusseriana: uma filosofia que não tem objeto - ou cujo “objeto único" é o vazio, nas palavras de François Matheron12 - mas implicações polêmicas e práticas (Althusser 11, p. 152.), que é exercida mas não ilustra ou se aplica a nada. Neste exercício, contudo, pretende-se anunciar a necessidade de categorias inteiramente novas com relação às que a filosofia sempre utilizou, como Sujeito, Origem, Causa, Essência etc. Enunciar "teseslimites" significa, portanto, propor esta renovação sem querer adiantar na proposição o resultado a que devem conduzir. Trata-se do que Althusser chama de "primado do materialismo" sobre a dialética na sua Sustentação de Tese: "para tornar as coisas mais claras, quando se rejeita a origem radical das coisas, faz-se indispensável forjar categorias inteiramente diferentes das categorias clássicas para pensar essas delegações de origem que são a essência, a causa ou a liberdade" (Althusser 5, p. 144). O fato de que já na década de 1970 Althusser adote tal posicionamento nos possibilita considerar seus últimos textos como consumação desta "subordinação da dialética".

A subordinação em questão assumirá a forma de uma rejeição de qualquer necessidade das determinações dos acontecimentos, seja políticos, seja filosóficos. Estamos diante de uma radicalização da "teoria da conjuntura" e, portanto, de uma ruptura com a teoria da necessidade da contingência - exposta anteriormente a partir da dialética de Marx - cujo predecessor seria Maquiavel.

Nos últimos textos achamos uma problemática comum e familiar a Althusser: a preocupação em definir o que seria "a verdadeira tradição materialista" ou a "tradição materialista aleatória explícita"
(Althusser 12, p. 180), "recalcada" ao longo da história da filosofia, da qual fariam parte Demócrito, Epicuro, Lucrécio, Maquiavel, Hobbes, Spinoza, Rousseau, Marx, Heidegger, Deleuze e Derrida. Se Althusser já havia apresentado a concepção da história da filosofia como luta entre idealismo e materialismo, trata-se agora de realizar uma "sondagem profunda"13 nesta história. Assim, no subterrâneo dela descobrimos um materialismo do encontro e da contingência, que deve ser recuperado do seu recalcamento para combater o idealismo e

(...) que se opõe como um pensamento inteiramente outro aos diferentes materialismos conhecidos, aí compreendido o materialismo frequentemente atribuído a Marx, a Engels e a Lênin que, como todo materialismo da tradição racionalista é um materialismo da necessidade e da teleologia, ou seja, uma forma transformada e disfarçada de idealismo (Althusser 12, p. 554)

Como vimos, a teleologia é uma posição ideológica em filosofia, pois determina a "origem radical" das coisas pela projeção de uma finalidade sobre a história. Há, por isso mesmo, um materialismo teleológico, especialmente no caso do marxismo: um discurso ideológico da inevitabilidade da revolução proletária, que redimirá a humanidade e inaugurará uma nova história no futuro. Isto seria, para Althusser, o oposto de uma leitura materialista de Marx.

Há, portanto, um verdadeiro deslocamento de problemática e estamos autorizados a falar mesmo em "ruptura epistemológica" de Althusser: da necessidade da contingência à contingência da necessidade: "em lugar de pensar a contingência como modalidade ou exceção da necessidade, é preciso pensar a necessidade como devir-necessário de encontros de contingentes" (Althusser 12, p. 581)14. Com efeito, é possível que um encontro dure e que, por isso, seja fixado na ordem histórica: mas 
ele o será sob uma instabilidade radical, sob a possibilidade da ocorrência de uma transformação aleatória.

Poderíamos, então, dizer que a teoria da necessidade da contingência seria uma forma para Althusser de lidar com o aleatório determinada pelos limites impostos pela ideia ainda dominante de seu tempo: a dialética? Como explicar a sua leitura singular de Marx, senão por essa tentativa de eliminar a teleologia hegeliana do horizonte teórico de Marx, tentativa mais adequada às questões da própria conjuntura teórica de Althusser? Essa tentativa resulta, ela mesma de uma subordinação da contingência à causalidade estrutural, que seria "a lei de todas as suas variações". No último Althusser temos, portanto, a "explosão" definitiva da contingência na direção de outro posicionamento filosófico. Uma repetição dos mesmos termos "necessidade" e "contingência"; mas a colocação da contingência "no poder", diante de uma conjuntura "aleatória", na sua leitura, como a da década de 1980.

\section{REFERÊNCIAS BIBLIOGRÁFICAS}

1. ALTHUSSER, Louis. La Revolución Teórica de Marx (Pour Marx). Buenos Aires: Siglo XXI Editores, 1967.

2. Elementos de Autocrítica. Barcelona: Editorial Laia, 1974.

3. L__ Lénine et la Philosophie suivi de Marx et Lénine devant Hegel. Paris: François Maspero, 1975.

4.___. Filosofia e Filosofia Espontânea dos Cientistas. Lisboa: Editorial Presença, 1976.

5. _. Resposta à John Lewis; Sustentação de Tese em Amiens. Rio de Janeiro: Edições Graal, 1978.

6.__ Ce qui ne peut pas durer dans le parti communiste. Paris: Fraçois Maspero, 1978.

7. . Ler O Capital. Tomo I. Rio de Janeiro: Zahar Editores, 1979.

8._L_ Ler O Capital. Tomo II. Rio de Janeiro: Zahar Editores, 1979.

9. Aparelhos Ideológicos de Estado. $7^{\mathrm{a}}$ ed. Rio de Janeiro: Edições Graal, 1985.
10

Freud e Lacan, Marx e Freud. $4^{\mathrm{a}}$ ed. Rio de Janeiro: Edições Graal, 1985.

11. O futuro dura muito tempo seguido de Os fatos. São Paulo: Companhia das Letras, 1992.

12. _ Écrits Politiques et Philosophiques. Tome I. Paris: Éditions STOCK/ IMEC, 1994.

13. DELEUZE, Gilles; GUATTARI, Félix. O que é a filosofia? 2ª ed. São Paulo: Ed. 34, 1997.

14. MATHERON, François. Présentation aux Écrits Politiques et Philosophiques Tome I de Louis Althusser. Paris: Éditions STOCK/IMEC, 1994.

\section{IN THE EMPTINESS OF A DISTANCE TAKEN - ALTHUSSER AND THE PRACTICE OF PHILOSOPHY}

Abstract: My aim is to discuss the conditions and implications of the displacement performed by Althusser from his inicial definition of philosophy as the "theory of theoretical pratice" to a later definition of philosophy as struggle and as positiontaking over the emptyness. We issue as an hypothesis that it would be accurate to apply to althusserian works the concept of an epistemological rupture or cut, and that it could lead us to understand the passage from the dialetical materialism to aleatory materialism as Althusser's own "theoretical revolution".

Keywords: Althusser; defintition; philosophy; pratice; struggle.

\section{NOTAS}

1. O estruturalismo não seria uma "filosofia de filósofos" mas uma "ideologia filosófica dos investigadores" em etnologia, lingüística, etc. "No limite (e isto pode se ler em certos textos de Lévi-Strauss, em certos lingüistas e em outros lógicos filosofantes) o estruturalismo (seria exato dizer certos estruturalistas) tende ao ideal da produção do real sob a combinatória de quaisquer elementos". Althusser 2, 1974, p. 41.

2. "Toda filosofia ocidental moderna, dominada pelo 'problema do conhecimento', está assim de fato dominada pela formulação de um 'problema' colocado nos termos e numa base teórica produzidos (pouco importa se conscientemente por uns e inconscientemente por outros) desse reconhecimento em espelho. Althusser 7, 1979, p. 55. 
3. Esta Introdução contém uma seção intitulada "O método da economia política", texto decisivo na formulação das teses de Pour Marx e Lire le Capital. Ela faz parte dos manuscritos redigidos por Marx entre 1857 e 1858, que constituem os Grundrisse der kritik der poltischen öikonomie (rohentwurf).

4. "Nunca desautorizei meus ensaios, não tive oportunidade de fazê-lo. Mas, em 1967, ou seja dois anos depois da sua aparição, na edição italiana de Lire le Capital (tal como em outras edições estrangeiras) reconheci que estes dois textos estavam afetados por uma tendência errônea. Indiquei a existência desse erro e lhe dei um nome: teoricismo". Althusser 2, 1974, p. 11.

5. Esta ideia de "processo sem sujeito nem fim(s)" aparecerá em Resposta a John Lewis (1972), texto no qual Althusser procura diferenciar a concepção da história em Marx, um processo cujo motor é a luta de classes, e aquela apresentada por Lewis a partir do jovem Marx, segundo a qual "os homens fazem a história".

6. Expressão utilizada por Althusser para designar a postura de Spinoza com relação ao "problema do conhecimento". Althusser 11, 1992, p. 192.

7. Como dizem Deleuze e Guattari, os personagens conceituais são, para o filósofo, "os que operam os movimentos que descrevem o plano de imanência do autor, e intervém na própria criação de seus conceitos”. Deleuze 13, 1997. p. 85.

8. Refiro-me a Ce qui ne peut plus durer dans le parti communiste. Althusser 6, 1978, p. 91.

9. Embora tenha sido publicado em brochura apenas em 1972, Lénine et la Philosophie foi uma conferência proferida na Société Française de Philosophie em 1968, logo depois do "curso de filosofia para cientistas" publicado como Filosofia e Filosofia espontânea dos Cientistas.

10. "Ela [a filosofia] intervém de outra maneira: enunciando Teses que contribuem para desimpedir a via para uma justa posição destes problemas”. Althusser 4, 1976, p. 27.

11. Tradução livre do seguinte trecho “(...) la philosophie est ce lieu théorique étrange où il ne se passe proprement rien, rien que cette répétition de rien. Dire qu'il ne se passe rien em philosophie, c'est dire que la philosphie ne mène nulle part puisqu'elle ne va nulle part (...)”. Althusser 3, 1975, p. 34.

12. "Não há uma palavra final de Louis Althusser: sua obra para no caminho, essencialmente inacabável. Mas se fosse necessário designar alguma coisa como o motor de sua produção teórica, nos arriscaríamos a mencionar o vazio. Da conjuração do vazio necessário do ensaio sobre Hegel, ao "vazio de uma distância tomada", de Lênin e a Filosofia, para terminar no vazio como "objeto único" da filosofia"; Tradução livre de "Il n'ya a pas de dernier mor de Louis Althusser: son œuvre s'arrête em chemin, essentiellment inachevable. Mais s'il fallait désigner quelque chose comme le moteur de sa production théorique, nous nous hasardons à mentionner le vide. De la conjuration du vide necessaire du mémoire sur Hegel au "vide d'une distance prise" de Lénine et la Philosophie, poru aboutir au vide comme "objet unique" de la philosophie". Matheron 14, 1994, p. 20.

13. Althusser compara seu método a uma sondagem profunda, tal como uma escavação petrolífera: "sabe-se que a pesquisa filosófica de grande profundidade faz-se por sondagens". Althusser 11, 1992, p. 150.

14. Tradução livre de “(...) au lieu de penser la contingece comme modalité ou exception de la nécessité, il faut penser la nécessité comme devenir-nécessaire de la recontre de contingents". 